\title{
THE EXPERIENCES OF THIRTEEN WOMEN MINISTERS OF THE METHODIST CHURCH OF SOUTHERN AFRICA
}

\section{Donald Williams}

Research Institute for Theology and Religion, University of South Africa donwill@telkomsa.net

\section{Christina Landman}

Research Institute for Theology and Religion, University of South Africa landmc@unisa.ac.za

\section{ABSTRACT}

The year 2016 marks the $40^{\text {th }}$ anniversary of the ordination of women into the ministry of Word and Sacraments in the Methodist Church of Southern Africa. What are their experiences during their ministry while being in a covenantal relationship with the church and their ordained colleagues? What are the particular concerns and issues raised by a sample of 13 women ministers who have served for a total of 90 years since their ordination in the church? This paper describes the unique relationship between the church and ministers and then presents the findings of the experiences of the sample, indicating that the women ministers in the Methodist Church of Southern Africa are being discriminated against in various ways, and are struggling to find acceptance and appointments in financially viable circuits.

Keywords: Covenantal relationship; ministry; Methodist Church of Southern Africa; ordination; ordained women in ministry

\section{INTRODUCTION}

The year 2016 is an important year in the life of the Methodist Church of Southern Africa (MCSA) in celebrating the $40^{\text {th }}$ anniversary of the ordination of women in

\section{UNISA $\cong$}


the MCSA. In the report of the General Secretary of the MCSA to the Conference of 2015, the Reverend Morgan, herself a women minister, stated: 'Starting now, we celebrate the Year of celebrating Women Clergy. 40 years after the Ordination of the first woman as a minister, $17 \%$ of our clergy are women, $4 \%$ of our Superintendents are women and no women are Bishops' (Methodist Church of Southern Africa 2016: 21).

Grassow and Cele (2016) trace the development of the ordination of women in the MCSA in the article " 40 years of women in ministry: Spotlight on Constance Oosthuizen" in the New dimension (2016), beginning with the Reverend Constance Oosthuizen. Her journey began in 1954 when the MCSA accepted her into the Diaconal Order, as women could not be ordained into the ministry of the Word and Sacraments. She studied overseas for two years and was then appointed to serve as a deaconess in the Rosettenville and Turffontein congregations for almost 20 years, during which time she 'experienced some opposition as a result of her being a woman, with congregants leaving her services because she was preaching' (New dimension, February 2016, 3). However, from 1972 the MCSA incorporated legislation into the Laws and discipline preparing for the acceptance of the ordination of women. In 1975 Oosthuizen was accepted as the first woman minister on trial and accepted into the ordained ministry of Word and Sacraments in 1976. She was appointed to serve at Port Shepstone, where she served for many years as a circuit minister as well as becoming the Warden of the Deaconess Oder of the MCSA. Oosthuizen's ordination was followed by Dorothy Spink (1978), Lindsay Hayward (1979), with the Reverend Nikiwe Mavis Mbilini (1985) being the first black woman minister to be ordained. 'Today, we have 133 women ministers in the church and women are free to candidate for the ministry' (New dimension, February 2016, 3).

While the MCSA celebrates the $40^{\text {th }}$ anniversary of the ordination of women, a number of people are raising questions regarding the acceptance of women ministers, that there are few in leadership positions, that women ministers are being discriminated against and that 'it is evident that women are treated badly in both black and white societies' (Mkhwanazi 2014, 33). A contributory factor would appear to be the nature of the relationship established between a minister and the MCSA at ordination, a relationship termed the 'covenantal relationship' (Methodist Church of Southern Africa 2014b, 94).

\section{THE EMPLOYMENT RELATIONSHIP OF MINISTERS WITH THE MCSA}

The covenantal relationship has a specific meaning within Methodist Church theology and polity. Upon ordination each minister is now in a specific and unique 
relationship with the Conference, ${ }^{1}$ authorised to function as a minister under the authority of the Conference in those circuits ${ }^{2}$ to which they are appointed; enjoying the colleagueship of other ministers in the Connexion ${ }^{3}$ and for whom the MCSA 'recognise(s) its pastoral responsibility to care for the welfare of its Ministers' (Methodist Church of Southern Africa 2014a, 30). This relationship is neither 'contractual' nor is there a 'legally enforceable contract' entered into between the parties (2014a, 30). It is a relationship into which ministers enter voluntarily, at their request, and are informed of the conditions under which they will fulfil their calling from God (Methodist Church of Southern Africa 2014a, 30).

The nature of the relationship has received growing attention from both the church and ministers in recent years. The legality of the covenantal relationship has also been challenged at the Commission for Conciliation, Mediation and Arbitration (C Wentzel and The Methodist Church of South Africa (GAJB 16127-10 [2011]) which found in favour of the church, upholding the legality of the covenantal relationship.

As the covenantal relationship impacts every aspect of the life and ministry of all ministers of the MCSA, the experiences of ministers while serving in the MCSA in terms of the covenantal relationship, was researched as part of the requirements for an MTh degree at the University of South Africa in 2015. A qualitative methodology was used to research the understanding and experiences of a representative sample of 42 ordained ministers by means of personal interviews, conducted in their own locality, which would not have been possible using the quantitative methodology. Thirteen of the participants were woman ministers. The grounded theory methodology of analysis, as described by Babbie (2012), to 'derive theories from an analysis of the patterns, themes, and common categories discovered in observational data' (Babbie 2012,336) was applied to the data in order to determine the findings of the experiences of the ministers.

The 13 women ministers represented 31 per cent of those interviewed, together having served 90 years following their ordination in ministry in circuit appointments. Of the sample, five were ministers of colour with many of the ministers having served both in rural and urban settings. In response to the question: 'Do you receive additional allowances above the minimum stipend?' 11 of the ministers stated that

1 The Conference provides direction and inspiration for the MCSA and is the MCSA's governing authority and supreme legislative body. Conference is the sole and final authority in respect of the doctrines of the church and their interpretation (Methodist Church of Southern Africa 2014a, 53).

2 Districts are divided into circuits, each consisting of a number of societies. Circuits oversee and coordinate the work of societies and promote and ensure the implementation of the mission imperatives of the MCSA throughout the Circuit (Methodist Church of Southern Africa 2014a, 73).

3 The South African Connexion comprises those ministers who serve in South Africa, Botswana, Lesotho, Mozambique, Namibia and Swaziland as different from those in Britain or the United States of America. 
the circuits had made provision for them to receive additional allowances above the minimum stipend stipulated by the MCSA in the annual Yearbook. However, eight of the 11 ministers who should have received additional allowances did not in fact receive their stipend or allowances during their ministry, some for months at a time.

\section{The experiences of ministers}

What was the experience of the 13 women ministers regarding their relationship with the MCSA and their experiences while serving in the MCSA?

\section{MINISTERS ARE CRITICAL OF HOW POWER IS MISUSED IN THE MCSA}

Every one of the 13 ministers interviewed indicated that she was unhappy with and had been impacted negatively by the covenantal relationship as it is presently constituted in the Book of Order (MCSA 2014a) and the annual Yearbook of the MCSA. They experience neither being in a covenant nor in a relationship, especially when a dispute arises between the church and ministers. In these circumstances they feel vulnerable and intimidated by the MCSA, in whose hands all the power is perceived to rest, and they do not experience the relationship as caring, Godhonouring or life-breathing. 'I feel that I am a $\mathrm{PF}^{4}$ number in a book somewhere. I am in a covenant with an impersonal institution with walls and offices and not with people' (Respondent 1). Another expressed her adverse experience stating: 'While completing my assignment with the Theological Education by Extension College, I learnt about being in a covenant. But I am not experiencing that loving, maturing, growth- empowering relationship in the covenant relationship with the MCSA. It is not really a relationship' (Respondent 11).

Ministers are adamant that in the covenantal relationship power is in the hands of the church which they believe misuses their powers leaving them feeling weak, helpless and vulnerable. 'I entered the ministry as a person who knew abuse and the church battered me more' (Respondent 4); 'The disempowered are not listened to' (Respondent 2); 'I suddenly had an extra year added to probation before ordination, thought to be five and now six years. In the first year the goal-posts shifted. This meant an additional year at seminary and delaying my ordination. I felt powerless, that I had not been heard and the impression was that I was less than nothing. I had to make a mind shift in order to cope' (Respondent 10); and 'We do not have a safe place to voice our convictions. No system protects me. I feel insecure' (Respondent 3).

4 Each minister is allocated a PF (Pension Fund) number which is the unique identifier in the MCSA's administrative system. 
The ministers interviewed are concerned at the impact of the misuse or abuse of power by all the structures of the church, including ministers, organisations, units and circuit officials. 'People in power, including ministers, get carried away in their positions and are not acting as servants' (Respondent 11). The Education, Mission and Ministry Unit (EMMU) was cited as an example. 'Changes are just imposed which affected our lives.' The attitude appeared to be 'Comply now. Complain later' (Respondent 10). The fact that the ministers could not turn to structures outside of the church to deal with the issues they were facing, and that the MCSA could make decisions which affected their lives without consultation or discussion, resulted in them feeling insecure and vulnerable. A third said: 'I am not so much upset at the use of power by officials as the unethical way power is used' (Respondent 6).

The dominant experience of the misuse of power is in the stationing of ministers by the MCSA, often into financially non-viable circuits or the church insisting on a move which is disruptive for the minister and her family. Ministers experience the stationing process as disempowering and are concerned that they are not adequately consulted or listened to. 'The church doesn't really listen to us and we are scared to be vocal and then land up without a station. If you speak the truth to those in power, you may land up nowhere. So let me suffer silently' (Respondent 13). The word 'abusive' was used to describe the manner in which 'being placed at the foot of stations' is used to discontinue ministers from the ministry (Respondent 3 ).

The ministers indicated that the MCSA is dealing with a cycle of violence and that this cycle needs to be broken, a cycle which begins during their formation years when they experience the misuse of power by their superintendent ministers, circuit officials, district officials and by EMMU. 'If we are formed autocratically we will do that to others' (Respondent 11). A similar understanding is discerned in the statement: 'I learn from the way I am superintended. The cycle of the misuse of power needs to be broken by establishing more healthy relationships at connexional, ministerial, organisational and circuit levels' (Respondent 12).

Ministers also experience the misuse of power in the disciplinary processes such as the holding of commissions of enquiry and pastoral commissions, which seem to be on arbitrary grounds or as a means for the structures of the church to impose their will. Ministers are suspicious of pastoral commissions as they appear to be manipulated to serve the interests of the church and recommendations are not followed through. 'You get no recognition as a minister in the MCSA for living out your call. Yet should a couple of people be dissatisfied you suddenly find yourself being investigated in a pastoral commission. Where is the grace? And then proposals and findings of pastoral commissions are just swept under the carpet. They just disappear' (Respondent 8). 


\section{THE MINISTERS EXPERIENCE BEING DISCRIMINATED AGAINST}

The 13 ministers felt that they had been discriminated against during their formation and while serving in the MCSA. This discrimination takes various forms and is experienced differently by each person. However, the common themes raised by the women ministers will now be examined.

They believe that they are discriminated against by entering into the covenantal relationship with the MCSA and then by superintendent ministers, their male colleagues and a dominant male orientation within the MCSA. An example of such rejection is of a superintendent minister saying to a woman minister appointed to his circuit: 'I won't have a woman minister in my circuit. I don't want you. You will only be here for a year. The church made a mistake in accepting you.' Her reaction to the words of this superintendent was: 'I was speechless and went through hell' (Respondent 7).

In addition, they experienced discrimination from their male and female colleagues. 'The MCSA has not discriminated against me. My colleagues have and it has affected my relationships with them...I didn't sign up to be abused by colleagues' (Respondent 6). Another minister responded saying: 'I am concerned about the power-play among ministers. Ministers are threatened by each other. As a female person I am not taken seriously nor respected. There is not trust among ministers' (Respondent 7). A third response is: 'As female black ministers we are not taken seriously. We have to break that cycle of female ministers having to prove themselves, being regarded as inferior. There is no trust among black female ministers arising from a lack of confidence in themselves. The church needs to empower the people after 40 years of women ministers' (Respondent 13).

The women ministers also believe that they are discriminated against by male persons in leadership positions within circuits and societies as a consequence of a patriarchal culture which leads to women ministers not being accepted. They experience circuit officials misusing their power by lobbying and acting beyond their mandate in the invitation of ministers and by influencing people to withhold their financial contributions. This results in ministers not receiving their stipend and allowances, being moved to another circuit or not being stationed at all. 'In the black church stipends are used to get rid of ministers' (Respondent 12). Ministers who are single experience circuits exploiting their circumstances as 'an opportunity to generate money'. For example, 'they want to rent out the manse and hire a flat because you don't have a family' (Respondent 1). Their concern is that officials and those in leadership roles do not always act in good faith in their dealings with women ministers. 'Males can ask for something and get it but as a female that doesn't happen' (Respondent 12). 'Male is the norm' (Respondent 13). 
Another way that the women ministers believe they are discriminated against is being stationed in non-viable or rural circuits where they are likely to be prejudiced financially. The covenantal relationship entitles the MCSA to station ministers in those circuits which are not financially viable, knowing that the ministers will probably not receive their stipend and/or other allowances and they may not appeal for relief outside of the church structures. 'You can't go AWOL if you are not paid and two years later you are regarded as deemed to have resigned' (Respondent 1). In addition, in these rural circuits there is often a traditional understanding that a minister must be a male person in order to be able to perform all the ministerial duties.

A concern raised was of retired and serving ministers improperly influencing the invitation of women ministers to a circuit and interfering in the business of circuits. Those interviewed also spoke of how the ministers manipulate the circuit structures and create power groups to support their invitation to continue ministering in viable circuits. 'Ministers become disempowered through stationing so they hold on to stations as a change could result in future difficulties' (Respondent 8).

And lastly, a different understanding of discrimination was the frustration expressed by one minister at the expectations of the circuit upon her having to fulfil her roles as the circuit minister, mother to her family as well as fulfil the expectations and responsibilities normally carried by the minister's wife. In a black context, this would include chairing the Women's Manyano, attending conventions, superintendents' consultations and the Minister's Wives Retreat. 'It is unfair...I get tired, tired, tired. I have to do it all' (Respondent 12).

Many of these responses are reflected in the study by Mkhwanazi (2014 and 2015) in statements such as: 'It is clear that women ministers in the church are not free. They have expressed their anger at not being accepted in the church by some male counterparts in the Mission Dei' (Mkhwanazi 2014, 89) and: 'In the majority of cases, many ordained women ministers are stationed in rural circuits where they cannot cope with challenges such as African traditional stereotypes against women in ordained ministry. The problem is worsened by a lack of solidarity between women themselves to fight against their exclusion and marginalisation. More often than not, their own internal divisions make it easy for them to become victims of male-dominated societies' (Mkhwanazi and Kgatla 2015, 182).

\section{THE MINISTERS AND THEIR FAMILIES ARE NEGATIVELY IMPACTED}

The data indicate that being stationed in rural and/or non-viable circuits also negatively impacts the families of the ministers. They refer to the large number of circuits in arrears with their circuit assessments, with those ministers being in danger of not receiving their stipend and allowances. This assertion is supported by the Lay 
General Treasurer who reported to the Conference of 2014 that ' 5 districts have more than $40 \%$ of their circuits in arrear [sic]' (Methodist Church of Southern Africa 2015, 27).

As mentioned earlier, eight of the 11 ministers interviewed should have received additional allowances, but experienced not receiving their stipend or allowances during their ministry - some for months at a time. They have, therefore, used up all their savings, are experiencing financial stress, are dealing with additional tensions within the family and are financially destitute, with one minister declaring: 'Every twenty-fifth of the month I am panicking if I am going to get my stipend...I am listed at the credit bureau' (Respondent 5). 'The covenant relationship can compromise you financially and then you have no leg to stand on' (Respondent 2), was another response.

'I did not receive a stipend or allowances for the first four months in Phase $1 .{ }^{5}$ I felt vulnerable. It drained me of all my financial resources. I was emotionally in a bad place. I had left my support group and now had no finances or a support system' (Respondent 10). Another stated: 'Not receiving my stipend caused tensions in me. I need to be protected at this stage of my life. I have no other income, support or back up' (Respondent 3). Consequently, ministers look for every opportunity to be moved from a non-viable circuit to a financially viable circuit and resist being sent to nonviable circuits, realising that they are not only prejudiced during their ministry but will also receive reduced benefits on retirement.

The financial burden of ministers is exacerbated by their portion of medical costs through the TopMed Medical Plan. They cite that 'having to pay up front is a problem' (Respondent 7). Another concern was the inability to pay the large copayments for hospitalisation, scans, spectacles and medication. Some ministers report having been assisted by the circuit or their local society, while others did not receive such support. A minister was unhappy that while 'TopMed can't provide for my child's needs, the church won't assist me to transfer to a scheme where adequate cover is possible' (Respondent 8).

A frequent theme raised by the ministers was the negative impact that the covenantal relationship had on their family. For many, their children have an adverse attitude to the MCSA and/or towards Christianity. A source of concern is that the children of five of the ministers have withdrawn from the life of the MCSA and want nothing to do with the denomination; some even want nothing to do with the Christian Church. 'As a result of where I was stationed and incidents in my ministry, my children will not darken a church' (Respondent 4). Children are concerned about the well-being of their parents, with a child asking: 'Where is the justice in the church allowing their own people to go without a stipend when they speak of justice issues all the time? How can the church treat you in that way?' (Respondent 3) and

$5 \quad$ Phase 1 is the first year of training of a minister during which they receive practical training in a circuit and communal training in Soweto, dealing with spiritual formation and academic input. 
another said: 'It pains my children to see their mother working and then not getting her stipend' (Respondent 5).

The problem of being an absent parent is a danger in all relationships and professions, including the Christian ministry, which was addressed by a minister who reflected that: 'We so easily become neglectful of our families' (Respondent 7). Further investigation pointed to the pressures of having to succeed and bring in money (or face being placed at the foot of stations), as one of the primary factors contributing to women ministers being absent parents. The absence of family time and the necessity of having to send children to boarding school, or for them to do their schooling away from home, were also raised as causes of concern.

Two further matters raised by the ministers were that, as the woman of the house, the circuit officials should be held accountable for the condition of manses, the quality of the furnishings provided, the unsuitable working environment from which ministers are often expected to function, and the unsuitable conditions in which to raise a family (Respondent 8). And lastly, the wife of a ministerial couple indicated that she and her husband have not been able to participate together in the sacrament of Holy Communion for a number of years; that they were treated as unmarried persons on occasions during their training, and that: 'We don't have lives together' (Respondent 9).

\section{Concerns regarding the credibility of the ministerial office}

A concern for the credibility of the office of a minister and the conduct of ministers was frequently raised by those interviewed. While they felt that the MCSA needs to be held accountable for their actions and decisions, they equally believe that their colleagues need to be held accountable for unacceptable actions and behaviour. Their observations are that many ministers are selfish, for whom status and power are important, whose pride and egos play large roles and who do not exhibit servant leadership. 'Ministers' hands are not clean. We need to deal with pride, ego and status among some ministers' (Respondent 11).

Four of the ministers interviewed were scathing of the poor work ethic of their colleagues and are critical of their lack of accountability to the church and their circuits, believing that ministers are not sufficiently held accountable for their performance as ministers. 'Ministers do what they like. We need to hold them accountable for their work performance and for them to take more responsibility for their actions and the outcomes of their actions' (Respondent 8). Another added: 'Anything goes for ministers. Ministers duck and dive and just go "missing in action"' (Respondent 4). Ministers are said to have expectations that are draining the financial resources of their congregations and are accused of 'eating money'. ${ }^{6}$ Their concern is that

6 'Eating money' is a euphemism for theft. 
ministers seem to get away by not being held accountable for such actions, or are moved to a new circuit without the issues being dealt with.

An associated concern was that ministers are not being held accountable by means of the annual review of ministers in terms of paragraph 4.82.1 of the Book of Order. 'For accountability purposes, every Minister's work shall be reviewed biannually through an interview process (Review of Ministry)' (Methodist Church of Southern Africa 2014a, 42).

This provision is experiencing resistance from ministers to be held accountable to their colleagues and it is not being implemented consistently throughout the MCSA, reflected in a statement such as: 'The annual review - what's that?' (Respondent 6). An associated problem is that ministers are reluctant to participate in the reviews as they do not always trust their superintendent minister regarding how the information they share is going to be used, particularly as a woman minister.

As ministers are critical of the work ethic, the under-performance, lack of accountability, misuse of power and being absent from their circuits, they need to take more responsibility for the perpetuation of these practices through their resistance to be held accountable themselves. In addition, the MCSA needs to address their responsibility in this regard, particularly since this requirement is laid down in the Book of Order (MCSA 2014a) but is being disregarded in most cases.

\section{NEED FOR CARE, CONSIDERATION, SUPPORT AND HEALING}

A recurring theme was the plea for more care, consideration and support at all levels of the MCSA. Ministers are disappointed at the lack of general caring, concern and pastoring received from bishops, MCSA officials, circuit officials, superintendent ministers and their colleagues. However, their responses indicated that the caring received varies widely from minister to minister, circuit to circuit, district to district, bishop to bishop, the nature of the support desired and the expectations of the ministers. The lack of caring by the church structures when ministers did not receive their stipends or allowances was most frequently raised by ministers, with only one minister speaking of a bishop applying for financial support to alleviate their financial stress. This response was closely followed by those who felt that they had not been cared for in times of pain or need and were disappointed that bishops are not able to give time to the pastoral care of their flock. 'We need a pastor to the pastors' (Respondent 8). And, finally, their appeal is that the MCSA should revisit the benefits received for medical assistance, with a special appeal for more assistance regarding emotional, psychological and spiritual wellness (Respondent 6). 


\section{EXPRESSIONS OF AFFIRMATION AND APPRECIATION}

In spite of the criticisms of the covenantal relationship and unhelpful experiences during their ministry, ministers expressed their appreciation for certain aspects of the covenantal relationship. Two reflections are: 'In spite of being drained financially and emotionally hurt by the covenantal relationship, I treasure the connexionality, support of colleagues and the provisions of a stipend, pension and assistance with medical expenses which all give me a sense of security' (Respondent 10); and 'The covenant relationship provides a safe framework within which to work. It provides security even if there are disappointments... While the covenantal relationship impacts ministers negatively in non-viable stations, this experience was also a time for personal growth for me. I had to decide how I was going to respond to my pain and I chose life instead of becoming negative' (Respondent 8).

Appreciation was expressed by those ministers who studied at the Seth Mokitimi Methodist Seminary where seminarians and staff are covenanted to each other by means of the 'SMMS Covenant' (Seth Mokitimi Methodist Seminary 2014). One minister expressed her appreciation saying: 'The SMMS Covenant was very helpful and positive. We were all equal and you laid yourself bare. My story was safe. Concerns were prayed for. There was accountability. However, that model is not always experienced in the greater church' (Respondent 11).

Others are appreciative of those in the church structures who did provide support and care, for example, their superintendent minister, colleagues and bishop, without which they would not have coped. They were also appreciative for the administrative support for tax, medical and pension administration provided by the Finance Unit of the Methodist Connexional Office. Others appreciated their time as seminarians for those who 'assisted in my spiritual formation' (Respondent 10) and to those circuits which are assisting with medical costs and ensuring that their families were provided for.

\section{ARE THEIR FINDINGS VERY DIFFERENT FROM THEIR MALE COLLEAGUES?}

Are the experiences/findings expressed by the women ministers markedly different from those of their men colleagues? What struck me during the interview process is that more women ministers spoke of being stationed in non-viable circuits than their men colleagues and, consequently, more women ministers spoke of their financial woes. The women ministers are more vigorous in their concern over the credibility of the office of a minister and are more critical of the work ethic and the lack of accountability of ministers. The women ministers are vociferous in expressing their condemnation of their pain at the spectrum of discrimination experienced by 
them, and the consequences of that discrimination leading to feelings of inadequacy, vulnerability, loss of self-worth and dis-empowerment.

\section{A way ahead}

While some of the women ministers wish the MCSA to move to a contractual relationship, for example one stating: 'Contracts will help ministers to know where they stand. Presently ministers have no recourse to the CCMA or for referral to anybody outside of the church's structures. All structures are self-preserving' (Respondent 4). The analysis shows that while both male and female ministers want changes to the present relationship with the MCSA, the women ministers are less inclined to ask for a contractual relationship than their male colleagues. Their wish is for a renewed covenantal relationship with the emphasis on relationships and accountability. 'While a contract will provide guidelines and accountability, the covenant relationship provides the opportunity for the enhancement of a relationship which is not possible in a contractual environment' (Respondent 10). Another said: 'If we go to contracts we will lose the important concept of servant leadership and we will end up with labour forums, such as unions and workers' committees' (Respondent 13). She then went on to say: 'We need a covenant relationship, but then really a covenant relationship, with caring, support, true inclusiveness and no disparities. There must be accountability. This relationship must be implemented from both sides' (Respondent 13).

\section{ACKNOWLEDGEMENTS}

\section{Competing interests}

The author declares that he has no financial or personal relationship(s) which may have inappropriately influenced him in writing this article.

\section{REFERENCES}

Babbie, E.R. 2012. The practice of social research (13 ${ }^{\text {th }}$ edition). Belmont: Wadsworth Publishing Company.

Commission for Conciliation, Mediation and Arbitration ( $C$ Wentzel and The Methodist Church of South Africa (GAJB 16127-10 [2011])

Grassow, L. and Cele, N. 2016. 40 years of women in ministry. New dimension, February 2016, p. 3.

Mkhwanazi, F.S. 2014. Women ministers in mission with reference to the Methodist Church of Southern Africa. PhD thesis. Department of Science of Religion and Missiology, University of Pretoria. 
Mkhwanazi, F.S. and Kgatla, T. 2015. The place of women ministers in the mission of the Methodist Church. Studia Historiae Ecclesiasticae 41(2): 180-197.

Methodist Church of Southern Africa. 2014a. The Methodist Book of Order: The laws and discipline of the Methodist Church of Southern Africa (12 ${ }^{\text {th }}$ edition). Cape Town: Methodist Publishing House.

Methodist Church of Southern Africa. 2014b. Yearbook 2014. Cape Town: Methodist Publishing House.

Methodist Church of Southern Africa. 2015. Yearbook 2015. Cape Town: Methodist Publishing House.

Methodist Church of Southern Africa. 2016. Yearbook 2016. Cape Town: Methodist Publishing House.

Seth Mokitimi Methodist Seminary. 2014. SMMS Covenant. Retrieved from: http://smms1. dyndns.org/index.php/about-smms/smms-covenant (accessed on 17 March 2016).

\section{Interviews}

Information relating to the interviews conducted:

$\begin{array}{lll}\text { Respondent } \rightarrow & 1 \rightarrow \text { on } \rightarrow \text { 13 November } 2014 \rightarrow & \text { at } \rightarrow \text { 10:00 } \\ \text { Respondent } \rightarrow & 2 \rightarrow \text { on } \rightarrow \text { 22 January } 2015 \rightarrow & \text { at } \rightarrow \text { 10:30 } \\ \text { Respondent } \rightarrow & 3 \rightarrow \text { on } \rightarrow \text { 22 January } 2015 \rightarrow & \text { at } \rightarrow \text { 14:00 } \\ \text { Respondent } \rightarrow & 4 \rightarrow \text { on } \rightarrow \text { 4 February } 2015 \rightarrow & \text { at } \rightarrow \text { 11:15 } \\ \text { Respondent } \rightarrow & 5 \rightarrow \text { on } \rightarrow \text { 9 February } 2015 \rightarrow & \text { at } \rightarrow \text { 11:30 } \\ \text { Respondent } \rightarrow & 6 \rightarrow \text { on } \rightarrow \text { 10 February } 2015 \rightarrow & \text { at } \rightarrow \text { 09:00 } \\ \text { Respondent } \rightarrow & 7 \rightarrow \text { on } \rightarrow \text { 12 February } 2015 \rightarrow & \text { at } \rightarrow \text { 09:00 } \\ \text { Respondent } \rightarrow & 8 \rightarrow \text { on } \rightarrow 17 \text { February } 2015 \rightarrow & \text { at } \rightarrow \text { 08:30 } \\ \text { Respondent } \rightarrow & 9 \rightarrow \text { on } \rightarrow 17 \text { February } 2015 \rightarrow & \text { at } \rightarrow 15: 00 \\ \text { Respondent } \rightarrow & 10 \rightarrow \text { on } \rightarrow \text { 23 February } 2015 \rightarrow & \text { at } \rightarrow 17: 30 \\ \text { Respondent } \rightarrow & 11 \rightarrow \text { on } \rightarrow \text { 23 February } 2015 \rightarrow & \text { at } \rightarrow 19: 00 \\ \text { Respondent } \rightarrow & 12 \rightarrow \text { on } \rightarrow \text { 24 February } 2015 \rightarrow & \text { at } \rightarrow 16: 00 \\ \text { Respondent } \rightarrow & 13 \rightarrow \text { on } \rightarrow \text { 25 February } 2015 \rightarrow & \text { at } \rightarrow 17: 00\end{array}$

Additional information (such as the names, localities and transcripts of the interviews of the respondents), has not been included in order to safeguard the anonymity of the respondents. This information is, however, in my possession. 